\title{
PROFIL DARAH DAN TINGKAT KERUSAKAN HATI PADA SAPI BALI YANG DI- GEMBALAKAN DI TEMPAT PEMEROSESAN AKHIR SUWUNG DENPASAR
}

\author{
ARDANI T.I.A.S*, W.S. YUPARDHI* DAN I N.T.ARIANA** \\ *Program Studi Magister Ilmu Peternakan, Universitas Udayana \\ ** Fakultas Peternakan, Universitas Udayana \\ coksygdias@yahoo.com
}

\begin{abstract}
ABSTRAK
Daging dapat terkontaminasi oleh parasit melalui pencemaran primer dan pencemaran sekunder. Salah satu kontaminasi yang sering dijumpai pada sapi bali adalah penyakit cacing hati atau Fascioliasis. TPA Suwung yang berfungsi sebagai tempat pemerosesan akhir sampah dari seluruh daerah di kota Denpasar kini dialihfungsikan oleh masyarakat sebagai tempat memelihara ternak. Makanan pokoknya hanya dari sampah-sampah di areal TPA yang secara fisik hampir tidak dapat dibedakan lagi jenisnya, semua bercampur dan membusuk. Sering kali sesuai permintaan, ternak dari TPA dijual Pasar Hewan atau langsung ke tukang potong yang akhirnya dikonsumsi oleh masyarakat. Hasil penelitian menunjukkan, semakin kecil rasio albumin:globulin maka semakin besar jumlah telur cacing yang terdapat dalam feses sapi bali yang dipelihara di TPA dan dan sapi kontrol dalam satuan telur per gram (tpg). Sebaliknya semakin sedikit jumlah telur semakin tinggi rasio albumin:globulin. Dapat disimpulkan bahwa tidak terdapat hubungan antara rasio albumin:globulin dalam serum darah, namun terdapat hubungan yang nyata antara jumlah telur cacing dalam feses dengan persentase kerusakan hati sebagai pendugaan kerusakan hati akibat Fascioliasis. Densitas telur cacing parasit usus pada hewan ternak sapi yang dipelihara di TPA bernilai <500 tpg, menunjukkan bahwa hewan ternak sapi tersebut tergolong mengalami infeksi ringan cacing parasit sehingga daging masih aman untuk dikonsumsi.
\end{abstract}

Kata kunci : Fascioliasis, TPA Suwung, rasio albumin:globulin, feses, hati.

\begin{abstract}
Meat can be contaminated by primary and secondary pollution. Contaminant often found in bali cattle is the liver fluke disease or Fascioliasis. TPA Suwung as a place of final waste processing is now being transformed as a place to rearing cattle. Only staple food from the trash-garbage in the landfill area that is physically indistinguishable species, all mixed up and almost rotting. Often the livestock of the landfill are sold to the market or directly to slughtered and than can be eat of the people. The research showed that the smaller ratio of albumin:globulin, the greater of worm eggs number found in the feces of bali cattle are reared in the TPA and bali cattle as control of eggs per gram (tpg). Vice versa the fewer worm eggs number, the greater albumin:globulin ratio in the blood. It can be concluded that there is not relationship between the albumin: globulin ratio in blood serum, but worm egg number in feses significant relationship with of liver damage from Fascioliasis. The density of worm eggs of intestinal parasites in cattle reared in TPA worth $<500$ tpg, shows that livestock reared in landfill Suwung Denpasar relatively mild infections, intestinal parasitic worms that meat are safe to eat.
\end{abstract}

Keywords: Fasciolosis, TPA Suwung, the ratio of albumin: globulin, feces, liver.

\section{PENDAHULUAN}

Dalam rangka memenuhi kebutuhan masyarakat terhadap protein hewani, berbagai upaya telah dilakukan oleh pemerintah untuk memenuhi pasokan daging ke pasaran, salah satunya dengan dicanangkan Program Pemenuhan Pangan Nasional. Khususnya di Bali, sapi bali memiliki potensi besar untuk dapat memenuhi kebutuhan daging, karena sapi bali mampu berproduktifitas yang relatif tinggi, kecenderungan populasi yang terus meningkat serta kemampuan adaptasi yang sangat baik. (Suweta, 1982).

Sejalan dengan usaha tersebut banyak peternak mengupayakan berbagai cara untuk dapat mensuplai daging sapi meskipun pemeliharaannya tidak sesuai dengan manajemen pemeliharaan yang baik. Dampak yang terjadi akibat manajemen pemeliharaan yang kurang baik misalnya kurangnya pengawasan terhadap kesehatan ternak dapat menghasilkan daging yang tidak sehat dan akan berdampak terhadap kesehatan 
masyarakat yang mengkonsumsinya (Aryatini, 1990).

Untuk memperoleh daging dalam kondisi bebas dari beberapa agen penyakit sangat susah dan jarang. Daging dapat terkontaminasi oleh parasit melalui pencemaran primer dan pencemaran sekunder. Pencemaran primer adalah pencemaran akibat parasit patogen sebelum ternak dipotong yang biasanya terdapat pada saluran pencernaan dan saluran pernafasan. Sedangkan pencemaran sekunder adalah terkontaminasinya daging setelah ternak dipotong yang dapat terjadi akibat alat pemotongan yang tidak steril, parasit patogen di udara, tempat pemotongan yang tidak higienis serta air pencuci yang tidak bersih (Buckle et al, 1985). Pencemaran primer jauh lebih memperburuk kualitas dan kesehatan daging yang dikonsumsi oleh konsumennya. Untuk menanggulangi pencemaran primer tersebut maka tindakan yang dapat dilakukan antara lain peningkatan hygiene dan sanitasi pemeliharaan, serta pengendalian penyakit menular (Aryatini, 1990).

Salah satu penyakit yang sering dijumpai pada ternak sapi bali adalah penyakit cacing hati atau Fascioliasis. Penyakit ini merupakan penyakit parasit yang disebabkan oleh cacing hati Fasciola hepatica yang umumnya menyerang ternak ruminansia dan dapat juga terjangkit pada manusia (Soulsby, 1968).

Hati merupakan kelenjar vital yang sangat penting untuk dijaga kesehatannya. Hati merupakan kelenjar terbesar didalam tubuh yang memiliki fungsi terpenting yang dapat mempengaruhi proses metabolisme dalam tubuh. Menurut Schalm (1975) dan Harper (1979) bahwa hati merupakan satu-satunya sumber pembentukan fibrinogen, protombin dan albumin serta memproduksi sebagian besar $\alpha$ dan $\beta$ globulin. Penurunan rasio albumin:globulin dapat terjadi apabila terjadi sirosis, hepatitis akut, abses hati dan penyakit yang disebabkan oleh parasit (Bush, 1975).

Hati seekor sapi dapat mengandung 200 ekor cacing atau lebih. Karena jumlah telurnya sangat banyak, maka telur akan keluar dari tubuh ternak melalui saluran empedu atau usus bercampur kotoran. Infestasi pertumbuhan cacing hati sangat mengganggu dalam proses pertumbuhan dan pembentukan daging. Hal ini disebabkan oleh perubahan konsentrasi protein dalam otot yang diproduksi oleh hati (Kariadi, 2010). Jaringan otot mengandung protein yang sangat banyak dan nilai nutrisinya tinggi. Protein otot tersebut terdiri atas aktin dan myosin (Cole, 1966). Protein lain yang terdapat didalam otot adalah "pigmen respiratoria myoglobin" yang berfungsi seperti $\mathrm{Hb}$ dalam darah (Swenson, 1977).

Tempat Pembuangan Akhir (TPA) Suwung Denpasar yang fungsi utamanya sebagai tempat pembuangan akhir sampah dari hampir seluruh wilayah di kota Denpasar kini banyak dialih fungsikan oleh masyarakat sebagai tempat memelihara ternak. Sapi bali yang dipelihara di TPA Suwung tersebut tidak dikandangkan, tidak dimandikan, pakannya hanya berupa limbah dapur, limbah sayur dan limbah buah - buahan. Pakan utamanya adalah sampah-sampah yang ada di areal TPA Suwung. Pemeliharaan ternak sapi yang sudah bertahun-tahun oleh beberapa peternak sapi dengan memanfaatkan sampah kota di area TPA menghasilkan produksi ternak sapi yang cukup bagus. Sapi-sapi yang digembalakan di TPA Suwung terlihat cukup gemuk dan pertumbuhan ternaknya cukup cepat. Secara teori produksi ternak ditentukan oleh beberapa faktor antara lain genetik dan lingkungan. Lingkungan dalam hal ini adalah manajemen pemeliharaan seperti perkandangan, pencegahan penyakit dan pakan (Sriyani, et al. 2014).

Tidak menutup kemungkinan, bahwa pakan yang ada di TPA Suwung salah satunya merupakan agen atau tempat hidup cacing hati. Mengacu dari permasalah tersebut diatas penelitian dilaksanakan untuk mempelajari status profil darah dan tingkat kerusakan hati yang diakibatkan oleh infeksi cacing hati dengan melihat populasi telur cacing hati pada feses sapi - sapi yang digembalakan di TPA Suwung.

\section{MATERI DAN METODE}

\section{Sapi Bali}

Penelitian ini dilakukan dari bulan Februari sampai dengan April 2015. Ternak sapi yang digunakan dalam penelitian ini adalah sapi bali betina afkir berumur diatas 4 tahun dengan jumlah total 18 ekor (9 ekor diternakkan di TPA Suwung dan 9 ekor diternakkan secara intensif di peternakan rakyat Nandini Pemogan). Pada sembilan ekor ternak sapi yang diambil secara acak guna mewakili TPA serta 9 ekor diambil dari ternak sapi yang dipelihara secara intensif sebagai kontrol.

\section{Variabel yang Diamati}

Variabel yang diamati dalam penelitian ini antara lain nilai albumin dan globulin serum diperoleh dengan metode biuret menggunakan alat Spectrophotometer Varian DMS 100. Pemeriksaan feses dilakukan dengan metode apung menggunakan saringan dengan ukuran 250 $\mu$ yang ada dalam 4 kamar alat hitung kaca universal Whitlock. Berdasarkan penghitungan menurut Whitlock (1948) jumlah telur cacing yang terdapat pada 4 kamar hitung (n) dikalikan 10 (tpg $=\mathrm{n} \mathrm{X} \mathrm{10).}$ Hati yang terinfestasi ditimbang dalam keadaan utuh kemudian bagian yang mengalami kerusakan diafkir dan ditimbang lalu dicari persentasenya. Metode analisis yang diterapkan adalah Uji "T" dalam hal ini variable yang diamati, yaitu jumlah telur cacing dalam feses yang bertindak sebagai variabel bebas (x) dan imbangan albumin:globulin sebagai variabel tak bebas (y). Tingkat signifikasi ditentukan pada taraf $5 \%(\mathrm{P}<0,05)$. 


\section{Analisis Data}

Metode analisis yang diterapkan adalah Uji "T" untuk membedakan antara kontrol dengan TPA (Chang, 1972). Dalam hal ini variable yang diamati, yaitu jumlah telur cacing dalam feses yang bertindak sebagai variable bebas (x) dan rasio albumin:globulin sebagai variable tak bebas (y). Tingkat signifikasi ditentukan pada taraf $5 \%(\mathrm{P}<0,05)$.

\section{HASIL DAN PEMBAHASAN}

Hasil analisis yang dilakukan di Laboratorium Daerah Provinsi memperoleh penghitungan imbangan albumin:globulin pada serum darah dengan pemeriksaan jumlah telur cacing dalam feses dan persentase kerusakan hati sapi bali yang diternakkan di TPA Suwung Denpasar dan Kelompok Ternak Sapi Nandini Pemogan dari ternak sapi betina berumur diatas 4 tahun yang diambil secara acak disajikan pada Tabel 1 .

Tabel 1. Hasil Analisis Albumin, Globulin, Imbangan Albumin:Globulin (A/G), Jumlah Telur Cacing pada Feses dan Persentase Kerusakan Hati Sapi Bali

\begin{tabular}{lccccc}
\hline & \multicolumn{5}{c}{ Variabel } \\
\cline { 2 - 6 } Perlakuan & $\begin{array}{c}\text { Albumin } \\
\mathrm{dL} \text { (g/ Globulin }\end{array}$ & $\mathrm{dL} / \mathrm{g} /$ & $\mathrm{A} / \mathrm{G}(\mathrm{g} / \mathrm{dL})$ & $\begin{array}{c}\text { Telur Cacing } \\
\text { (tpg) }\end{array}$ & $\begin{array}{c}\text { Tingkat } \\
\text { Kerusakan } \\
\text { Hati (\%) }\end{array}$ \\
\hline Kontrol & $3.7^{\mathrm{a}}$ & $3.9^{\mathrm{a}}$ & $0.93^{\mathrm{a}}$ & $98.89^{\mathrm{a}}$ & $16.00^{\mathrm{a}}$ \\
$\mathrm{TPA}^{\mathrm{a}}$ & $3.6^{\mathrm{a}}$ & $4.0^{\mathrm{a}}$ & $0.87^{\mathrm{a}}$ & $142.22^{\mathrm{b}}$ & $28.78^{\mathrm{b}}$ \\
$\mathrm{SEM}^{1}$ & 0.91 & 0.7 & 0.017 & 41.45 & 7.69 \\
$\Sigma$ & 7.3 & 7.9 & 1.8 & 241.11 & 44.78 \\
$\mathrm{X}$ & 3.65 & 3.95 & 0.9 & 120.56 & 22.39 \\
Standar & $2.1-3.6^{1)}$ & $2.9-4.9^{1)}$ & $1.1-1.5^{1)}$ & $50-90^{2)}$ & $5.0-10.0^{3)}$ \\
Normal & & & & &
\end{tabular}

Keterangan: huruf yang berbeda dalam satu baris menunjukkan perbedaan nyata $(P<0.05)$. Sumber: 1) Schalm (1975) \& Anderson, et al (1977) ; 2)Kosasih (1999) ; 3)Thienpont, et al., (1995)

Hasil dari penelitian ini yakni nilai albumin rata rata $3,65 \mathrm{~g} / \mathrm{dL}$ dengan nilai kontrol $3,7 \mathrm{~g} / \mathrm{dL}$ dan TPA 3,6 g/dL yang tidak berbeda nyata $(P>0.05)$. Nilai ini jika dirujuk dari standar normal menurut Schalm (1975) dan Anderson, et al. (1977) masih berada pada kisaran normal yakni $2,1-3,6 \mathrm{~g} / \mathrm{dL}$.

Pada nilai globulin dengan nilai rata- rata $3,95 \mathrm{~g} /$ $\mathrm{dL}$ diperoleh hasil yang tidak berbeda nyata $(\mathrm{P}>0,05)$ yakni pada kontrol diperoleh nilai globulin sebesar 3,9 g/dL sedangkan pada TPA diperoleh 4,0 g/dL. Dan jika dirujuk dari nilai standar normal menurut Schalm (1975) dan Anderson, et al. (1977) masih berada pada kisaran normal yakni 2,9-4,9 g/dL.

Demikian halnya dengan nilai dari imbangan albumin:globulin (A/G) yang memperoleh hasil ratarata $0,9 \mathrm{~g} / \mathrm{dL}$. Nilai kontrol yang diperoleh sebesar 0,93 $\mathrm{g} / \mathrm{dL}$ sedangkan pada TPA diperoleh nilai lebih rendah yakni $0,87 \mathrm{~g} / \mathrm{dL}$. Jika dibandingkan dengan nilai standar normal menurut Schalm (1975) dan Anderson, et al.
(1977) nilai imbangan A/G tersebut berada dibawah kisaran normal yakni 1,1-1,5 g/dL namun secara statistik tidak berbeda secara nyata $(\mathrm{P}>0,05)$.

Berbeda halnya dengan pemeriksaan pada feses untuk memperoleh jumlah telur cacing dalam feses dan nilai persentase kerusakan hati yang memperoleh hasil secara statistik yang berbeda nyata $(\mathrm{P}<0,05)$. Rata-rata jumlah telur cacing dalam feses adalah 120 , 56 tpg. Pada kontrol diperoleh jumlah telur dalam feses sebesar 98,89 tpg sedangkan pada TPA diperoleh jumlah telur cacing yang lebih besar yakni 142,22 tpg. Jika dibandingkan dengan standar normal menurut Kosasih (1999) jumlah telur cacing dalam feses ini jauh melebihi standar normal yakni sebesar 50-90 tpg.

Pada pemeriksaan terhadap persentase kerusakan hati, diperoleh nilai melebihi standar normal yang berada pada kisaran 5,0-10,0\% dan secara statistik berbeda nyata $(\mathrm{P}<0,05)$. Pada kontrol diperoleh nilai persentase kerusakan hati sebesar $16,00 \%$ sedangkan pada TPA $28,78 \%$ dengan nilai rata-rata $22,39 \%$.

Hasil pemeriksaan dan penghitungan 18 sampel feses ditemukan jenis telur cacing yang bervariasi. Jenis cacing yang dapat teridentifikasi dalam sampel feses tersebut antara lain Fasciola hepatica dan beberapa cacing jenis nematoda yakni Stromgyle spp., Strongyloides spp. dan Ascaris spp. dengan persentase yang berbeda-beda.

Tabel 2. Hasil Analisis Identifikasi Jenis Telur Cacing yang Terkandung dalam Feses Sapi Bali

\begin{tabular}{ccccc}
\hline \multirow{2}{*}{ Perlakuan } & \multicolumn{3}{c}{ Persentase Jenis Telur Cacing (\%) } \\
\cline { 2 - 5 } & $\begin{array}{c}\text { Fasciola } \\
\text { hepatica }\end{array}$ & Stromgyle spp & $\begin{array}{c}\text { Strongyloides } \\
\text { spp. }\end{array}$ & Ascaris spp. \\
\hline Kontrol & $67.2^{\mathrm{a}}$ & $8.94^{\mathrm{a}}$ & $8.08^{\mathrm{a}}$ & $15.78^{\mathrm{a}}$ \\
TPA & $60.8^{\mathrm{a}}$ & $12.4^{\mathrm{a}}$ & $12.46^{\mathrm{a}}$ & $14.17^{\mathrm{b}}$ \\
SEM $^{1}$ & 4.04 & 2.46 & 1.67 & 3.57 \\
$\Sigma$ & 128 & 21.3 & 20.54 & 29.95 \\
$\mathrm{X}$ & 64 & 10.65 & 10.27 & 14.98 \\
\hline
\end{tabular}

Dari hasil analisis identifikasi terhadap jenis telur cacing yang terkandung dalam feses sapi bali yang diternakkan di TPA dengan Kelompok Ternak Nandini diperoleh jenis telur cacing yang beragam yakni Fasciola hepatica dan beberapa cacing jenis nematoda antara lain Stromgyle spp., Strongyloides spp. dan Ascaris spp.. Dengan persentase tertinggi pada Fasciola hepatica sebesar 64\%, selanjutnya Ascaris spp. dan Stromgyle spp. masing - masing sebesar 14,98\% dan 10,65\% dengan persentase terkecil pada Strongyloides spp. sebesar $10,27 \%$.

Pada persentase jenis telur cacing Fasciola hepatica diperoleh hasil yang tidak berbeda nyata $(\mathrm{P}>0,05)$ yakni pada kontrol diperoleh persentase telur cacing sebesar $67,2 \%$ dan di TPA diperoleh nilai yang lebih kecil yakni $60,8 \%$. Pada persentase jenis telur cacing 
Stromgyle spp. diperoleh nilai $12,4 \%$ pada TPA dan 8,94\% pada kontrol yang secara statistic tidak berbeda nyata $(\mathrm{P}>0,05)$. Demikian juga pada hasil persentase jenis telur cacing Strongyloides spp. yang menunjukkan hasil yang secara statistic tidak berbeda nyata $(\mathrm{P}>0,05)$, pada kontrol diperoleh nilai persentase jumlah telur cacing Strongyloides spp. sebesar 8,08\% sedangkan pada TPA memiliki nilai persentase yang lebih besar yakni 12,46\%.

Berbeda halnya dengan persentase jenis telur cacing Ascaris spp. yang menunjukkan nilai yang berbeda nyata $(\mathrm{P}<0,05)$ dengan nilai persentase jenis telur cacing Ascaris spp. pada kontrol sebesar 15,78\% sedangkan pada TPA diperoleh nilai persentase lebih kecil yakni 14,17\%.

Tabel 3. Albumin, Globulin, Rasio Albumin:Globulin (A/G), Jumlah Telur Cacing pada Feses dan Persentase Kerusakan Hati Sapi Bali yang Diternakkan di TPA Suwung Denpasar dan Kelompok Ternak Sapi Nandini Pemogan

\begin{tabular}{|c|c|c|c|c|c|}
\hline No. & Albumin & Globulin & $A / G$ & $\begin{array}{l}\text { Telur Cacing } \\
\text { (tpg) }\end{array}$ & $\begin{array}{c}\text { Persentase } \\
\text { Kerusakan } \\
\text { Hati (\%) }\end{array}$ \\
\hline 1 & 3.6 & 4.1 & 0.87 & 160 & 45 \\
\hline 2 & 3.8 & 4.0 & 0.95 & 20 & 5 \\
\hline 3 & 3.9 & 4.3 & 0.91 & 60 & 10 \\
\hline 4 & 3.3 & 4.0 & 0.82 & 320 & 61 \\
\hline 5 & 3.2 & 3.8 & 0.84 & 100 & 9 \\
\hline 6 & 3.7 & 4.3 & 0.87 & 160 & 7 \\
\hline 7 & 3.5 & 4.1 & 0.85 & 200 & 56 \\
\hline 8 & 3.2 & 3.8 & 0.84 & 260 & 64 \\
\hline 9 & 3.8 & 4.0 & 0.97 & 10 & 2 \\
\hline 10 & 3.4 & 3.6 & 0.94 & 80 & 34 \\
\hline 11 & 3.1 & 3.8 & 0.81 & 420 & 72 \\
\hline 12 & 3.6 & 3.8 & 0.94 & 30 & 3 \\
\hline 13 & 3.9 & 4.0 & 0.96 & 20 & 6 \\
\hline 14 & 3.9 & 4.2 & 0.92 & 80 & 8 \\
\hline 15 & 3.8 & 4.0 & 0.96 & 40 & 7 \\
\hline 16 & 3.8 & 4.3 & 0.88 & 120 & 14 \\
\hline 17 & 3.7 & 3.9 & 0.94 & 40 & 5 \\
\hline 18 & 3.9 & 4.0 & 0.95 & 60 & 5 \\
\hline Jumlah & 65.1 & 72.0 & 16.24 & 2180 & 413 \\
\hline $\begin{array}{l}\text { Rata- } \\
\text { rata }\end{array}$ & 3.6 & 4.0 & 0.90 & 121 & 23 \\
\hline $\begin{array}{l}\text { Standar } \\
\text { Normal }\end{array}$ & $2.1-3.6^{1)}$ & $2.9-4.9^{1)}$ & $1.1-1.5^{1)}$ & $50-90^{2)}$ & $5-10^{3)}$ \\
\hline
\end{tabular}

Rata-rata imbangan albumin:globulin pada sapi bali betina berumur diatas 4 tahun yang diternakkan di TPA Suwung Denpasar dan Kelompok Ternak Sapi Nandini Pemogan adalah 0,90 (Tabel 1). Terlihat adanya penurunan imbangan albumin:globulin dari nilai normal imbangan albumin:globulin pada sapi bali yang diperoleh oleh Radostits (2007) dan Latimer (2011) yaitu 0,70. Hal ini sejalan dengan hasil penelitian yang dilakukan oleh Schalm (1975) dan Anderson dkk (1977) yang mendapatkan penurunan imbangan albumin:globulin pada sapi yang diinfeksi Fasciola hepatica yang turun dari standar normal yakni 1,1-1,5.

Dari Tabel 3 dapat diamati bahwa semakin kecil imbangan albumin:globulin maka semakin besar jumlah telur cacing yang terdapat dalam feses sapi bali yang diternakkan di TPA Suwung Denpasar dan Kelompok Ternak Sapi Nandini Pemogan dalam satuan telur per gram (tpg). Demikian pula sebaliknya semakin sedikit jumlah telur cacing maka semakin besar imbangan albumin:globulin dalam darah. Pada tabel 3 terlihat dari sampel no 11 dan no 9 yaitu imbangan $A / G$ paling rendah yaitu 0,81 dan jumlah telur cacing 420 tpg dengan persentase kerusakan hati $72 \%$ sedangkan imbangan A/G tertinggi yaitu 0,97 dengan jumlah telur cacing dalam feses 10 tpg dan persentase kerusakan hati $2 \%$. Semakin besar imbangan A/G maka dapat menekan persentase kerusakan hati, karena albumin dan globulin merupakan protein yang bisa meregenerasi sel parenkim hati (Latimer, 2011). Dalam hal ini untuk menduga tingkat kerusakan hati dapat dilakukan dengan cara pemeriksaan dan menghitung jumlah telur cacing dalam feses.

Terjangkitnya suatu penyakit tidak terlepas dari peranan pakan yang dikonsumsinya. Namun menurut Sriyani (2014) jenis pakan yang tersedia di TPA Suwung dan dikonsumsi oleh ternak sapi tersebut antara lain dari limbah sayuran, limbah buah-buahan dan limbah dapur. Limbah sayuran yang tersedia secara berkesinambungan di TPA Suwung antara lain, batang kangkung, kol, sawi, sayur hijau, tongkol jagung, kulit jagung (klobot), wortel, nangka, daun ketela, pohon, tauge, daun kayu manis dan daun jepang. Limbah berupa buah-buahan yang tersedia di TPA Suwung antara lain, kulit papaya, kulit melon, kulit pisang, kulit semangka dan kulit jeruk bali. Sedangkan limbah dapur yang selalu ada secara kontinyu di TPA Suwung antara lain, nasi sisa, roti serta ketela pohon.

Dari hasil identifikasi terhadap jenis limbah yang dikonsumsi secara kontinyu di TPA Suwung oleh ternak sapi, limbah sayuran berupa batang kangkung dapat dijadikan menjadi salah satu media perantara oleh hospes cacing Fasciola hepatica. Menurut Kosasih (1999), batang kangkung merupakan salah satu media perantara bagi hospes-hospes beberapa jenis cacing antara lain Fasciola hepatica dan Ascaris spp. namun kemungkinannya relative kecil. Hal ini terjadi karena kangkung merupakan sayuran yang tumbuh ditempat basah dan lembab, yang merupakan lingkungan tepat bagi pertumbuhan hospes Fasciola hepatica dan Ascaris spp.

Terjangkitnya Fascioliasis pada ternak sapi di TPA Suwung dapat terjadi karena beberapa faktor 
antara lain, terlewatnya sapi-sapi di TPA Suwung saat dilaksanakannya program pemerintah yakni "Program Pemberantasan Cacing Hati Pada Ternak Sapi”, adanya media perantara hospes diantara sampah-sampah yang ada di TPA Suwung serta manajemen pemeliharaan yang tidak sesuai. Hal ini dibuktikan dengan adanya banyak kasus ditemukannya cacing hati pada ternak yang di "kurbankan" saat inspeksi mendadak pada hari raya Idul Fitri dan Idul Adha oleh Dinas Peternakan dan Kesehatan Hewan Provinsi Bali (Anonim, 2014).

Selain itu terjangkitnya Fascioliasis pada ternak sapi di TPA Suwung juga dapat terjadi karena diberikannya pakan berupa rumput segar oleh peternak selama 6 (enam) bulan sebelum ternak sapi tersebut dijual ke pasar ternak Beringkit. Hal ini dilakukan untuk menetralisis kandungan timbal (Co) pada ternak sapi yang akan dijual pada saat hari raya Idul Adha dan Idul Fitri (Anonim, 2014). Dalam pakan rumput tersebut kemungkinan adanya hospes cacing Fasciola hepatica. Dalam proses pemberian pakan rumput selama 6 (enam) bulan ternak sapi tetap digembalakan di areal TPA Suwung dan fesesnya banyak ada di areal tersebut. Hal ini dapat berakibat tersebarnya hospes- hospes bibit cacing Fasciola hepatica di areal TPA Suwung.

Adanya cacing muda yang ditemukan pada hati sapi dapat terjadi karena ternak sapi tersebut baru saja terjangkit Fascioliasis, sehingga infeksinya belum akut. Akibatnya saat pemeriksaan terhadap feses, jumlah telur cacing dalam satuan telur per gram sangat sedikit dan menunjukkan hasil yang tidak signifikan. Ditemukannya sejumlah kecil telur cacing pada feses dapat terjadi karena cacing Fasciola hepatica pada hati masih muda dan belum bereproduksi atau belum bertelur (Kosasih, 1999).

Dari data Tabel 2 dapat dilihat bahwa telur cacing dari jenis Fasciola hepatica menempati urutan tertinggi dengan persentase 64\%, sedangkan Ascaris spp. menempati urutan kedua dengan persentase 14,98\%, diikuti oleh Stromgyle spp dengan persentase 10,65\% dan terendah oleh Strongyloides spp. dengan persentase $10,27 \%$.

Berdasarkan keterangan standar infeksi, maka infeksi dapat dibedakan yaitu infeksi ringan jika jumlah telur 1-499 butir per gram; infeksi sedang ditunjukkan jika jumlah telur 500 - 5000 butir per gram dan infeksi berat ditunjukkan jika telur yang dihasilkan > 5000 butir per gram feses ternak. Dari standar tersebut dapat dinyatakan bahwa ternak sapi Bali yang diternakkan di TPA Suwung Denpasar masih tergolong infeksi ringan karena telur yang dihasilkan oleh cacing parasit usus < 500 butir telur per gram feses (Thienpont, et al., 1995) .

Namun yang harus diingat adalah ditemukannya jumlah telur cacing per gram feses ternak tidak selalu dapat menunjukkan tingkat infeksi yang sebenarnya.
Hal ini mengacu pada kenyataan bahwa hanya cacing dewasa saja yang dapat menghasilkan telur, sedangkan larva cacing belum menghasilkan telur. Larva kemudian menjadi dewasa secara seksual, dan ada yang menjadi cacing jantan yang juga patut diperhitungkan untuk menentukan tingkat infeksi pada hewan ternak sapi. Jumlah telur yang diproduksi dengan jumlah telur yang ditemukan per gram feses ternak dipengaruhi oleh faktor cacing jantan, larva, resistensi hospes dan tingkat infeksi cacing parasit usus tersebut serta kadar serat kasar yang terdapat pada pakan ternak sapi. Makin banyak kadar serat kasar pada pakan ternak sapi maka makin sedikit jumlah telur cacing dalam feses sapi yang diternakkan di TPA Suwung Denpasar dan Kelompok Ternak Sapi Nandini Pemogan (Kosasih, 1999).

\section{SIMPULAN}

Dapat disimpulkan bahwa tidak terdapat hubungan antara rasio albumin:globulin dalam serum darah, namun terdapat hubungan yang nyata antara jumlah telur cacing dalam feses dengan persentase kerusakan hati sebagai pendugaan kerusakan hati akibat Fascioliasis. Densitas telur cacing parasit usus pada hewan ternak sapi yang dipelihara di TPA bernilai $<500$ tpg, menunjukkan bahwa hewan ternak sapi tersebut tergolong mengalami infeksi ringan cacing parasit sehingga daging masih aman untuk dikonsumsi.

\section{DAFTAR PUSTAKA}

Anonim. 2010. Program Pemberantasan Cacing Hati Pada Ternak Sapi. Dinas Peternakan dan Kesehatan Hewan Provinsi Bali Diunduh pada tanggal 24/10/2014. Tersedia di http://disnakbali.go.id/2014qw.pdf

Aryatini dan Hernawati, 1990. Fisiologi Ternak. Fenomena Dasar Interaksi Organ pada Hewan. Penerbit Kusumadjaja. Surabaya

Anderson, P.H., B. Sylvia., J.B. Pamela, H.C. Nancy, J.W. Parfitt,and D.S.P. Patterson. 1977. Biochemical indicators of liver injury in calves with experimental fascioliasis. The Veterinary Record., 100. 43-45

Buckle, G.C., E.J.M., Carrol, and JT. Busher. 1985. Serum Albumin and Globulin Clinical Methods.Didalam $\mathrm{H}$ Kenneth Walker HK, Dallas MD, Hurst JW, editor:The History, Physical, and Laboratory Examinations. Edisi ke 3. Editor. Butterworth Publisher Emory University School of Medicine, Atlanta, Georgia, Boston.

Bush, B.M. 1975. Veterinary Laboratory Manual. William Heinemann Medical Books Ltd. London

Cole, E.H., 1966. Veterinary Clinical Phatology. $3^{\text {rd }}$ Ed. W.B Sounders. Company Philadelphia. London.

Harper. 1979. Review of Physiological Chemistry. Lange Medical Publications. California

Kariadi, M. 2010. Fisiologi Hewan. Penerbit Widya Padjajaran. Bandung

Kosasih, dan Nurmayati. 1999. Parasit Pada Ternak Unggul. 
Edisi I. Penerbit Wijayakusuma. Semarang

Latimer K.S, J.R. Duncan, E.A. Mahafrey, and K.W. Phrasse. 2011. Duncan and Prasse's Veterinary Laboratory Medicine: Clinical Pathology. Edisi 5. Iowa State Press. Wiley Blackwell. Iowa. hlm. 374

Radostits, O.M, C.C. Gay, K.W. Hinchcliff, and P.D. Constable PD. 2007. Veterinary Medicine: A Textbook of The Diseases of Cattle, Sheep, Pigs, Goats, and Horses. Edisi 10, Elsevier Health Sciences, Philadelphia, PA, USA.

Schalm, O.N. 1975. Veterinary Hematology. $3^{\text {rd }}$ Ed. Department of Clinical Pathology of Veterinary Medicine. University of California. Lea and Febiger. Philadelphia.

Soulsby, E.J.L. 1968. Helminth, Arthopodes and Protozoa of Domesticated Animals. $7^{\text {th }}$ Ed. Bailliere Tyndall.

Sriyani, N.L.P., I.N. Tirta Ariana, I.G.L.O. Cakra. 2014. Potensi Sampah Kota Sebagai Sumber Pakan Terhadap Produk Fermentasi Rumen Dan Kandungan EPA (Eicosapentaenoic Acid) Dan DHA (Dokosaheksaenoic Acid) Daging Sapi Bali. MSBL - 28.

Suweta, I.G.P. 1982. Kerugian Ekonomi oleh Cacing Hati pada Sapi Bali Sebagai Implikasi Interaksi dalam Lingkungan Hidup pada Ekosistem Pertanian di Pulau Bali. Universitas Padjajaran. Bandung

Swenson, M.J. 1977. Duke's Physiology of Domesticated Animals. $8^{\text {th }}$ Ed. Cornel University Press. Ithaca and London

Thienpoint. 1995. The Inspection of Worm Eggs in Animals Feces. $13^{\text {th }}$ Ed. Cornel University Press. Ithaca and London 